\title{
When the grace period is over: Assessing the new Member States' compliance with EU requirements for oil stockholding
}

\author{
Jale Tosun* \\ Department of Politics and Management, University of Konstanz, Box D 91, 78457 Konstanz, Germany
}

\begin{abstract}
A B S T R A C T
The accumulation of appropriate emergency stocks of crude oil and petroleum products has been at the heart of the European Commission's efforts to increase the security of supply. This study investigates how effectively the 'new' Member States comply with the requirements of Council Directive 2006/67/EC, which imposes the obligation to maintain minimum stocks of crude oil and/or petroleum products. The empirical focus of this analysis is not only motivated by the practical relevance of this issue, but also by the fact that eleven of the twelve new Member States were given grace periods between one and seven years to bring their national stockholding arrangements in line with the European requirements. The granting of extended deadlines raises the question whether this instrument indeed facilitates the transposition process. The empirical findings show that except for Latvia, compliance with the EU stockholding requirements is generally very good. A more detailed analysis of the Latvian case highlights that the transposition delays principally stem from budgetary constraints. More generally, the individual new Member States' capacity to cope with the financial burdens and the degree of adjustment pressure determine the variation in oil stock levels.
\end{abstract}

European Union

New Member States

Emergency oil stocks

\section{Introduction}

Questions about how effectively Member States comply with the legal provisions of the European Union (EU) have been at the heart of Europeanisation research. A well-developed body of research has outlined numerous determinants of the correct and timely transposition of European directives. Although the literature is very diverse, the overarching finding is that domestic variables are central to the effectiveness of the transposition process. In this regard, the Member States' administrative capacities and the preferences of domestic veto players were found to possess the highest explanatory power (Treib, 2008, p. 17; see also König and Luetgert, 2008; Mastenbroek, 2005; Tallberg, 2002). More recent studies further underline the relevance of the characteristics of the national decision-making process (see, e.g. Steunenberg and Kaeding, 2009).

Most of the existing studies focus on the transposition behaviour of the 'old' Member States. So far, only few analyses have explored the transposition of Community law in the 'new' Member States, i.e. the countries that entered the EU in 2004 and 2007, respectively. How well do the new Member States transpose European legislation? Which factors determine their transposition behaviour? With regard to the first question, Sedelmeier (2008) finds that the new Member States on average

\footnotetext{
*Tel.: +497531 882301; fax: +497531 882381.

E-mail address: jale.tosun@uni-konstanz.de
}

have a better transposition record than the old Member States. With regard to the determinants of the transposition behaviour, Toshkov (2008) shows that similar to the findings for the old Member States, political preferences and government capacity are the most important predictors for the likelihood of timely transposition. There is, however, one important characteristic about the new Member States that needs to be taken into account when evaluating their transposition performance: all new Member States were given extended deadlines, so-called grace periods, for meeting certain requirements of European law. ${ }^{1}$

Generally, within the then 31 chapters of the accession negotiations the individual Member States were granted transitional arrangements for different policy measures. For example, in the chapter on environmental policy. Slovenia benefited from grace periods for legislation on the recovery and recycling of packaging waste, treatment of urban waste water, and integrated pollution prevention and control. Other accession candidates' transitional arrangements referred to different environmental policy measures.

\footnotetext{
' For the purpose of the present study, the conception of transitional periods is that they are intended to help the new Member States to meet the provisions defined by the EU. By the same token, however, transitional arrangements were also defined in order to 'protect' the old Member States. Most importantly, the freedom of movement of workers from Central and Eastern European countries has been temporarily limited in this vein. For a discussion of the 'discriminatory' use of transitional periods, see Schneider (2009).
} 
Hence, in most cases, the sector-specific directives affected by grace periods varied from one country to another.

Things look, however, markedly different in the area of the energy policy, in which, except for Hungary, all accession candidates received extended deadlines for one and only one directive, namely Council Directive 98/93/EC (replaced by Council Directive 2006/67/EC of 24 July 2006) that obliges Member States to build up emergency oil stocks corresponding to at least 90 days of the average daily internal consumption in the preceding year. Why did the accession candidates (almost) uniformly ask for transitional arrangements for meeting the provisions of this particular directive? What does the transposition situation look like now that the grace period has ended for most of the new Member States?

The present study pursues the objective of identifying the specific costs related to the transposition of the European legislation on emergency oil stocks. Most empirical studies treat cost parameters in an abstract manner and come up with very general definitions. While this makes perfect sense for studies that aim at explaining broad patterns of EU law transposition, such a general approach is less desirable for learning about policy-specific costs and benefits. In this way, the study aims to contribute to the newly emerging research perspective on post-accession compliance (see, e.g. Cirtautas and Schimmelfennig, 2010; Falkner and Treib, 2008; Schimmelfennig and Trauner, 2009; Sedelmeier, 2008) as well as the literature on European energy policy (see, e.g. Buchan, 2009, 2010; Morata and Solorio, 2011; Strandberg, 2010).

The empirical findings will show that the main reason for which the accession candidates asked for special arrangements was the need to organise the necessary investments. Despite the financial burdens emerging from the EU stockholding requirements, nine of the ten Member States for which the extended transposition deadlines had ended in December 2009 were found to be in full compliance with Council Directive 2006/67/EC. It is only the government of Latvia that has faced difficulties in building up sufficient emergency stocks for two of the three regulated oil types. The transposition delays in the case of Latvia can be explained by the unavailability of any financing from the state budget in the years 2009-2011. The new Member States' absolute levels of emergency oil stocks, however, are not only determined by the financial burdens but also stem from the extent of institutional incompatibility and adjustment pressuie.

The study proceeds as follows. Section 2 gives an overview of the general development of the EU's energy security policy, focusing in particular on the issue of emergency oil stocks. Section 3 presents the arguments advanced by the accession candidates during the negotiation of the energy chapter in order to receive transitional periods. In a next step, Section 4 introduces the main arguments elaborated by studies of post-accession compliance and puts forward hypotheses. Subsequently, data on the situation of emergency oil stocks in 2008 and 2011 is presented in Section 5. A detailed analysis of the Latvian case and an exploration of the determinants of absolute stock levels in all new Member States are presented in Section 6. Section 7 concludes the study by summarising the key findings.

\section{General characteristics of European energy legislation}

European energy policy is an area in which major achievements have only recently been made. Although the EU evolved out of the European Coal and Steel Community and the Euratom Treaty, the Community is still in the process of developing energy concerns into a coherent policy field. For a long time, the Member States blocked the further policy integration as they considered energy issues to be of primary national political importance (Padrós and Cocciolo, 2010, p. 33; Pointvogl, 2009, p. 5704). In spite of this unfavourable political context, some progress regarding energy policy harmonisation could be achieved and the Member States are in fact becoming increasingly willing to transfer regulatory powers to the EU (see Correljé and van der Linde, 2006; Pointvogl, 2009).

In this regard, a regulatory hallmark is represented by the European Commission's 1997 White Paper for a 'Energy for the Future: Renewable Sources of Energy'. Another step forward can be seen in the 2006 Green Paper entitled 'A European Strategy for Sustainable, Competitive and Secure Energy', which paved the way for the European Commission to receive a mandate for the elaboration of a coherent EU energy policy (see Nilsson et al., 2009). The entering into force of the Lisbon Treaty in January 2010 prepared the ground for another major step forward, that is, the adoption of the European Commission's Communication 'Energy 2020-A strategy for competitive, sustainable and secure energy' (see, e.g. Solorio, 2011).

This strategic document outlines the Community's energy priorities for the period between 2011 and 2020 and defines the following core objectives of European energy policy: (1) achieving energy efficiency, (2) developing a pan-European integrated energy market, (3) empowering consumers and achieving energy safety and security; (4) extending the EU's leadership in energy technology and innovation, and (5) strengthening the external dimension of the European energy market. In this context, the European Commission (2011, p. 10) has also underlined that oil remains the primary energy source, which means that emergency oil stocks will continue to constitute a central aspect of the European policy on energy security.

\subsection{Emergency oil stocks as an instrument for ensuring energy security}

The European Commission has historically requested competences in energy security, which led to its proactive approach with regard to emergency oil stocks (Buchan, 2010, p. 368). In theoretical terms, coordinated stockholding of sufficiently large regions yields benefits that are often substantially larger than the sum of the individually optimal reserves (Leiby et al., 2002; for a more critical discussion, see e.g. Emerson, 2006). In light of this theoretical perspective, the European Commission's efforts to strengthen joint stockholding must be judged as justified for achieving the objective of energy security (see Chester, 2010, p. 891).

Following a recommendation of the Organisation for Economic Cooperation and Development (OECD), and considering the unstable situation of the international oil markets, on 20 December 1968 the European Council issued Directive 68/414/EEC, which for the first time laid down the obligation on Member States to build up and maintain emergency stocks of oil and/or petroleum products at a level corresponding to at least 65 days' average daily internal consumption in the preceding calendar year. Right from the beginning, the European system of mandatory oil stocks was patterned after the obligations defined by the International Energy Agency (IEA).

Council Directive 72/425/EEC raised the obligation to develop stocks equivalent to at least 90 days of internal consumption. Moreover, Council Directive 73/238/EEC obliged the Member States to take appropriate measures to mitigate difficulties in the oil supply. In addition to developing emergency stocks, in the event of supply disruptions the Member States were required to impose restrictions on consumption, to give priority to supply certain groups of users, and to regulate prices to hinder abnormal price increases (Willenborg et al., 2004, p. 27). The stockholding 
provisions were further strengthened by Council Directives 98/93/EC and 2006/67/EC. To bring the EU rules fully in line with the IEA's accounting methodology, in 2009 Council Directive 2009/119/EC was adopted, which needs to be transposed by 31 December 2012 (see Bankes-Hughes, 2011, p. 36).

\subsection{Requirements of Council Directive 2006/67/EC}

As it is the objective of this study to scrutinise the new Member States' compliance with the currently valid legislation, the empirical focus is laid on Council Directive 2006/67/EC (henceforth: the Directive). Principally, the Directive requires the Member States to build up and maintain at all times minimum stocks of petroleum products equal to at least 90 days of the average daily internal consumption during the previous calendar year. Member States that have their own petroleum production may deduct this proportionally from their stockholding obligation. However, the deduction is limited to a maximum of 25 per cent of the respective member state's internal consumption. The calculation of the daily internal consumption is based on three categories of oil and petroleum products:

- Category I: motor spirit and aviation fuel (aviation spirit and jet fuel of the gasoline type).

- Category II: gas oil, diesel oil, kerosene and jet-fuel of the kerosene type (middle distillates).

- Category III: fuel oils.

In order for stocks to be counted towards meeting the legal provisions, the Member States' governments need clearly established statutory powers to take control over the stocks in the event of supply disruption. Stockholding arrangements must ensure that the stocks are available to and accessible by Member States so they can react immediately in the event of a supply crisis. The Directive further demands that the Member States send the European Commission a statistical summary of the stocks existing at the end of each month, stating the number of days of average consumption of the previous calendar year. The reporting obligation covers a wide range of issues such as the date on which the stocks fell below the compulsory minimum, reasons for withdrawal, steps taken to build the stocks back up, and likely stock levels during the period in which they will remain below the compulsory minimum.

The stockholding obligations can be met, for example, through supplies held in refinery tanks, tanks at the entry to oil pipelines, inter-coastal tankers, in inland ships' bunkers, and oil tankers in ports. Compliance with the Directive is also attained when stock cover is arranged through leasing agreements. Such 'tickets' are generally a cost-effective way for meeting stockholding obligations since they substitute for directly acquiring oil stocks and building or renting necessary storage capacity. The Member States can also establish stocks within the territory of another Member State. In order to use these stocks towards meeting the stockholding obligations, a specific storage agreement between the two governments concerned must exist, which confirms that the stocks remain at the free disposal of the Member State on whose behalf the stocks are held.

\section{The negotiation of the energy chapter}

States aspiring to become members of the EU have to transpose the acquis communautaire (henceforth: the acquis), i.e. the entirety of Community law. The incorporation of the 80,000 pages strong body of Community law represents an immense political and administrative effort. In view of this impressive volume of obligatory policy and institutional reforms, "it is a genuine puzzle (and one that has remained largely unnoticed) that the postcommunist countries have been rather successful in adapting to EU law" (Toshkov, 2008, p. 380). There is indeed empirical evidence that the new Member States perform well with regard to the formal transposition of EU legislation (see, e.g. Sedelmeier, 2008). However, when interpreting the transposition performance, one must pay attention to the fact that the European Commission granted the accession candidates additional time to adjust to new policy requirements.

In contrast to some other parts of the acquis, the negotiation of the energy chapter did not take much time. For example, in the cases of Latvia, Lithuania, Malta and Slovenia the negotiations were completed after only about a year, i.e. in 2001 and 2002. At first glance, one might think that this was caused by the absence of any critical issues in this particular chapter. In fact, the complete opposite was the case as a series of controversial points appeared on the agenda. Of these, the new Member States' nuclear reactors were among the most hotly debated ones. Slovakia, for example, had to close two units of the Bohunice-V-1 nuclear power plant by 2006 and 2008, respectively (see Lofstedt, 2008). Likewise, Lithuania was forced to decommisșion the two units of the Ignalina 1 nuclear power plant (see Katinas et al., 2008; Miskinis and Deksnys, 2003) and Bulgaria had to close down units 1 and 2 of the Kozloduy nuclear power plant (see Semov, 2005).

Furthermore, the accession candidates faced notable difficulties in transposing the legislation on the internal energy market. In many of the new Member States, planning economy structures as a legacy of the state-socialist past are still visible in the energy sectors. For example, a major impediment to effective market opening in Poland has been the slow process of privatisation in the electricity and gas sectors as many political actors oppose the idea of privatised energy companies (Nowak, 2007, p. 82). Also, some of the new Member States simply hesitated to give up their recently acquired independence to a new international structure reducing their national sovereignty in questions of the energy market (Eikeland 2008, p. 46).

In view of these difficulties one would have expected that the accession candidates asked for special arrangements with regard to their nuclear power plants or the directives on the internal energy market. Instead, they solely requested grace periods for complying with the legal obligations regarding emergency oil stocks. It was only the Hungarian government that refrained from asking for an extended transposition deadline as the country was ahead of the other accession candidates in terms of emergency oil stocks. The reason for this is that the country already attached a high political priority to energy security in the early 1990s due to its dependence on oil imports for three quarters of its supplies (IEA, 2001, p. 149f.). Consequently, the Hungarian government enacted relevant legislation in 1993 and in 1997 the country became an IEA member (EIHP-PDC, 2011, p. 21). With its accession to the IEA Hungary was already effectively complying with the international stockholding obligations.

Generally speaking, to receive a grace period the applicants have to convince the European Commission that there are serious impediments to a timely transposition of the legal provisions. With regard to oil stockholding, the most rampant argument was that the development of sufficient emergency stocks was too costintensive to be accomplished within such a short period of time. The Maltese government, for instance, explained that it would be overwhelmed by the costs of purchasing the required stocks and constructing more storage space. In order to absorb the impact of these costs, the Maltese government requested more time to spread them over a six-year period (Times of Malta, 2002). Even countries that started relatively early to align their stockholding 
systems with the European requirements were confronted with considerable adjustment challenges. In Poland, for instance, the creation of emergency stocks already began in 1998 (with an initial stock level of about seven days average daily consumption), but the country still had to apply for an extended transposition deadline (Material Reserves Agency of Poland, 2011).

In light of the plausibility of the cost implications related to stockpiling, the European Commission was willing to grant transition periods ranging from one year (for the Czech Republic and Slovenia) to seven years (for Bulgaria and Romania). However, the European Commission was generally unwilling to accept excessively postponed transposition deadlines, which is well illustrated by the case of Lithuania. To be sure, the Lithuanian government originally asked for a grace period of seven years, but it only received an extension of six years (Umbrasas, 2001). All in all, it can be stated that all accession candidates but Hungary had to demonstrate considerable efforts to meet the EU requirements for emergency oil stocks.

\section{Compliance with the EU's oil stockholding system: theoretical expectations}

The Europeanisation literature has shown that ineffective transposition might be the result of the degree of 'misfit' between domestic policies and institutions on the one side and the requirements emerging from European legislation on the other side (see, e.g. Börzel, 2000; Duina, 1997; Knill and Lenschow, 1998; Mastenbroek, 2005; Treib, 2008). In a nutshell, this theoretical perspective posits that greater degrees of misfit increase the adaptation pressure on a given country, which in response might become less willing or able to carry out the necessary adjustments. In this regard, Knill and Tosun (2009), for instance, argue that transitional arrangements such as grace periods should lead to reduced short-term adaptation pressure and therewith increase the likelihood of effective compliance with Community law through granting additional temporal flexibility (see also Perkins and Neumayer, 2007). Following this reasoning, countries benefiting from longer grace periods can be expected to perform better regarding the transposition of Council Directive 2006/67/ EC than those that were given shorter ones.

Hypothesis 1a. Longer grace periods lead to better compliance with the EU requirements for emergency oil stocks.

An alternative analytical perspective on extended transposition deadlines is that they indicate persistent adjustment problems in certain areas of EU law. As explained in the previous section, the European Commission usually does not grant any grace periods unless the requesting government is confronted with a serious problem hampering timely compliance with EU law. Following this opposite view, countries benefiting from long grace periods can be regarded as being confronted with high adaptation pressure, which the Europeanisation literature would regard as a predictor for imperfect compliance. Further, as the extended transposition deadlines allow for postponing the need to tackle the existing misfit between domestic and European stockholding systems, the countries might pass up a change to launch necessary reforms. Thus, a competing hypothesis on the impact of adjustment pressures is put forward, which takes into account the possibly negative incentive provided to the new Member States' government by granting them longer grace periods.

Hypothesis 1b. Longer grace periods lead to imperfect compliance with the EU requirements for emergency oil stocks.

While the duration of the granted grace periods is certainly an important indicator for assessing the degree of adjustment pressure faced by the individual countries, it is equally important to take into consideration their membership with the IEA. To recall, the European legislation on emergency oil stocks has been patterned in a way to correspond to the IEA obligations. Thus, IEA membership means that the countries have to re-design their national stockholding systems in order to meet the international standard. From this it follows that the degree of misfit and the resulting adjustment pressure for transposing the Directive are lower for those countries that are IEA members. In this regard, it is important to note that longer IEA membership should additionally reduce the adjustment pressure as this entails that the necessary reforms were already carried out a while ago.

Hypothesis 2. Longer membership in the IEA leads to better compliance with the EU requirements for emergency oil stocks.

In addition to institutional incompatibilities and adjustment pressure, the literature on post-accession compliance suggests another important factor for explaining compliance patterns. This research strand argues that the drivers of policy making in the pre-accession stage differ from those of the post-accession stage. Before becoming EU members, the overriding political goal in the accession countries was almost exclusively oriented towards adopting the acquis in order to conclude the accession negotiations (Cirtautas and Schimmelfennig, 2010; Schimmelfennig and Trauner, 2009; Sedelmeier, 2008). After completing this process, however, policy making became increasingly affected by domestic factors that were virtually ineffective during the pre-accession stages, thus the core argument of this literature.

How can these considerations inform a theory-led explanation for compliance patterns regarding emergency oil stocks? Which domestic factors are relevant? It is plausible to expect that crosscountry variation stems from differences in the governments' capacity to bear the financial costs stemming from the formation and maintenance of emergency oil stocks. To be sure, the previous chapter on the negotiation of grace periods highlighted that the majority of accession candidates justified their positions by making reference to the financial costs associated with an extension of their oil stocks. Countries with a prospering economy are thus more likely to be able to bear the financial burdens associated with the development of emergency oil stocks than those affected by economic downturn.

Hypothesis 3. A favourable economic situation leads to better compliance with the EU requirements for emergency oil stocks.

In a similar vein, the financial costs of oil acquisition should be lower in those new Member States that can cover a greater share of the necessary stock levels by domestic oil production (see EIHP-PDC, 2011; IEA, 2001). From this it follows that compliance with the European requirements for emergency stocks should be positively influenced by a country's oil production capacity, which gives way to the fourth and last hypothesis.

Hypothesis 4. A greater domestic oil production capacity leads to better compliance with the EU requirements for emergency oil stocks.

To sum up, based on Europeanisation research and the literature on post-accession compliance, two factors should crucially determine the new Member States' compliance with the European stockholding requirements. The first factor is the degree of adjustment pressure emerging from incompatibilities between domestic and European stockholding systems. The second factor refers to the capacity of bearing the financial costs that emerge from the transposition of the Directive. 


\section{Assessing compliance with Council Directive 2006/67/EC}

This section takes stock of the current situation in the twelve countries that joined the EU in 2004 and 2007. Most of the data used is publicly available. For learning about some specific aspects of oil stockholding, experts in the relevant organisations in the Czech Republic, Latvia, Poland, and Slovakia were approached. The presentation of the empirical material involves an overview of the current stock levels as the most important aspect of the Directive and a brief characterisation of the Member States' stockholding systems.

\subsection{Overview of the oil stock levels}

How effective is the implementation of Council Directive 2006/67/EC after the end of the transitional periods? As the Directive obliges the Member States to prepare monthly reports on the situation of their stock levels, this question can be easily evaluated. Table 1 is based on the official statistics provided by Commission's Directorate General (DG) for Energy on its website. It presents the average stock levels given in days of consumption for the three regulated types of oil and petroleum products for the years 2008 and 2011. The values for 2008 are reported for a better assessment of the current stock levels; it is the first year for which DG Energy provides publicly accessible data. It should be noted that the values for 2011 are averaged over the period from January to July, 2011, whereas the values for 2008 are averaged over the entire year. Values printed in bold indicate average stock levels that are below the 90-days obligation.

The table further mentions the dates by which full compliance with the Directive was expected and the duration of the grace periods in years. It highlights that of the countries entering the EU in 2004, the Baltic States benefited from the most generously extended transposition deadlines. Regarding Hungary it should be recalled that compliance with the Directive was requested right with the country's accession to the EU on 1 January 2004. For the sake of completeness, the current levels for Bulgaria and Romania are also reported, although both countries are only expected to meet the obligatory stock levels by the end of 2012 .

Table 1 yields several interesting insights regarding the state of emergency oil stocks. Firstly, in 2008 five countries had not met the 90-days obligations for at least one of the three oil categories.

Table 1

Average compliance performance with Council Directive 2006/67/EC

\begin{tabular}{|c|c|c|c|c|c|c|c|c|}
\hline \multirow[t]{3}{*}{ Members } & \multirow{3}{*}{$\begin{array}{l}\text { Extension } \\
\text { Date }\end{array}$} & \multirow{3}{*}{$\begin{array}{l}\text { Extension } \\
\text { Years }\end{array}$} & \multicolumn{6}{|l|}{ Days } \\
\hline & & & \multicolumn{2}{|c|}{ Category I } & \multicolumn{2}{|c|}{ Category II } & \multicolumn{2}{|c|}{ Category III } \\
\hline & & & 2008 & 2011 & 2008 & 2011 & 2008 & 2011 \\
\hline Hungary & 01.01 .2004 & 0 & 95 & 112 & 91 & 106 & 411 & 589 \\
\hline $\begin{array}{l}\text { Czech } \\
\text { Republic }\end{array}$ & 31.12 .2005 & 2 & 98 & 110 & 92 & 105 & 127 & 151 \\
\hline Slovenia & 31.12 .2005 & 2 & 95 & 90 & 91 & 92 & 115 & 141 \\
\hline Malta & 31.12 .2006 & 3 & 98 & 96 & 120 & 103 & 119 & 88 \\
\hline Cyprus & 31.12 .2007 & 4 & 88 & 91 & 96 & 102 & 96 & 106 \\
\hline Poland & 31.12 .2008 & 5 & 114 & 123 & 113 & 115 & 198 & 380 \\
\hline Slovakia & 31.12 .2008 & 5 & 86 & 96 & 85 & 96 & 93 & 107 \\
\hline Estonia & 31.12.2009 & 6 & 60 & 102 & 56 & 101 & 118 & 124 \\
\hline Latvia & 31.12 .2009 & 6 & 42 & 1 & 45 & 2 & 304 & 281 \\
\hline Lithuania & 31.12.2009 & 6 & 74 & 106 & 78 & 98 & 144 & 158 \\
\hline Bulgaria & 31.12 .2012 & 7 & 47 & 82 & 44 & 74 & 87 & 109 \\
\hline Romania & 31.12 .2012 & 7 & 83 & 88 & 59 & 67 & 256 & 293 \\
\hline
\end{tabular}

Notes: Own elaboration based on the following website: < http://ec.europa.eu/ energy/observatory/oil/stocks_en.htm > accessed on 13 August 2011. All fuel types include crude oil and intermediate product stocks converted into finished products.
Of these, four still benefited from a grace period whilst for Cyprus the transitional period had already expired at the end of 2007. To be fair, however, the country complied with the requirements for oil categories II and III, and with an average stock level of 88 days it was very close to meeting the 90-days threshold for oil category I.

Secondly, and turning to the situation in 2011, the Czech Republic, Estonia, Hungary and Poland possess oil stocks for all three categories that are well above the required 90 days and even exceed volumes corresponding to 100 days. Of these countries, Hungary clearly outperforms the others with regard to the stock levels for fuel oil (i.e. oil and petroleum products of category III). However, it is Poland that displays the highest levels for oil and petroleum products of categories I and II. In this context, the Estonian stock levels are remarkable since in 2008 these were well below the 90-days threshold for two of the three oil categories.

Thirdly, the stock levels are generally high for fuel oil. Even Bulgaria and Romania already possess more than sufficient stock levels for this particular oil category. The high stock levels can be principally attributed to the lower acquisition costs. Fuel oil comprises heavier oil or oil with higher viscosity that is cheaper than refined oil such as diesel. The only exception from the generally high stock level for fuel oil is Malta, for which the average value for the year 2011 is about two days below the obligatory level. This comparatively low average value is caused by a short-term lowering of the stock levels in spring 2011 to 85 days. In July 2011, however, the country had again met the 90-days requirement.

Fourthly, all new Member States for which the grace periods had expired after December 2009 comply with the stockholding for oil of categories I and II. However, Latvia represents an importance exception from this compliance situation as the 2011 average stocks levels only correspond to one and two days; respectively. The stocks started to go down in September 2010 and culminated in a critical situation in April 2011 when the level for category I oil equalled zero days and two days for category II oil. Hence, in the case of Latvia there is indeed an evident situation of non-compliance with Council Directive 2006/67/EC.

To gain a better impression of the variation in the stock levels for oil categories I and II over the entire observation period, i.e. 2008-2011, Fig. 1 presents country-specific box plots. Box plots are a widely applied tool in descriptive statistics. The 'box' consists of the lower and the upper quartiles of the observations.

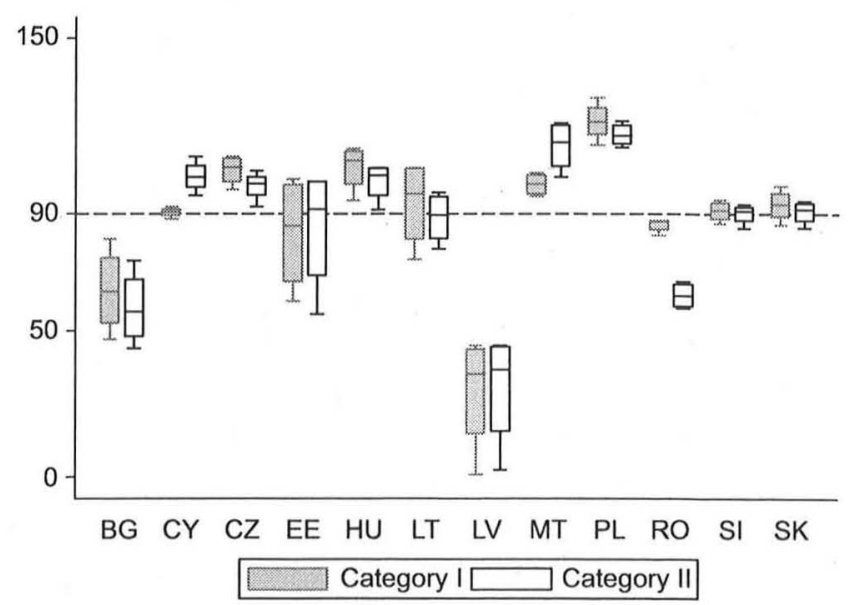

Fig. 1. Box plots of stock levels for oil categories 1 and II (2008-2011). Notes: Own elaboration based on information available at the following website: $<$ http://ec. europa.eu/energy/observatory/oil/stocks_en.htm >, accessed on 13 August 2011. 
The band near the middle of the box corresponds with the median. The lines at both ends of the box (i.e. 'whiskers') represent the minimum and maximum of all the data. It generally holds that the larger the box and the longer the whiskers, the greater is the variation in the data.

The box plots show that the data structure is compact for Cyprus, the Czech Republic, Hungary, Poland, Slovenia and Slovakia. This means that between 2008 and 2011 these countries managed to maintain relatively stable stock levels for the two oil categories. It should also be noted that for both oil categories the stock levels never fell below of the 90-days obligation (indicated by the dashed line in Fig. 1) in the Czech Republic, Hungary, Malta and Poland. By the same token, the stock levels of Cyprus (for oil category I), Estonia, Lithuania, Slovakia and Slovenia are both above and below of the 90-days requirement.

Then, there are four Member States that are characterised by great variation in their stocks levels, i.e. Bulgaria, Estonia, Latvia and Lithuania. Of these, the Latvian case is the most remarkable one since the maximum stock levels roughly correspond with the minimum stock levels of Bulgaria, which still benefits from a grace period. The location of the box plot for Latvia underscores the impression gained from Table 1 that the country is confronted with persistent problems in meeting the stockholding requirements of Council Directive 2006/67/EC for oil categories I and II.

Fig. 2 presents the country-specific box plots for oil category III. When inspecting the figure, it immediately becomes apparent that

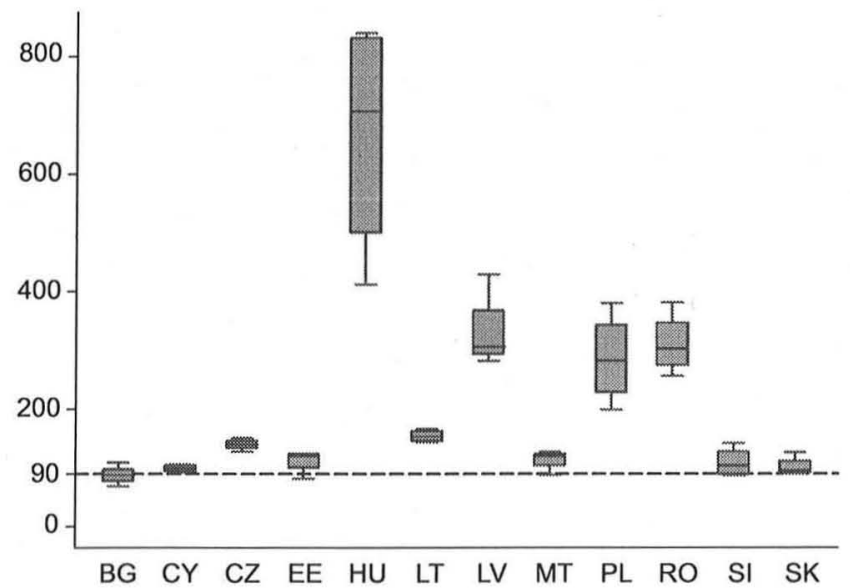

Fig. 2. Box plots of stock levels for oil category III (2008-2011). Notes: Own elaboration based on information available at the following website: < http:/lec. europa.eu/energy/observatory/oil/stocks_en.htm > accessed on 13 August 2011. compliance with the obligatory stock levels for this oil category has been unproblematic, even in the case of Latvia.

\subsection{Overview of stockholding structures in the new Member States}

Under EU legislation Member States are free to choose their specific stockholding arrangements, which brought about different systems across the Member States. Basically, the stockholding systems vary with regard to whether the stocks are solely managed by a governmental unit or agency, or whether they are based on mixed systems in which public entities cooperate with the industry. Table 2 gives an overview of the main actors involved in oil stockpiling activities and indicates whether in 2011 the respective Member State also held a part of the stocks outside its national territory.

Table 2 shows that most new Member States have mixed systems in place, in which a governmental unit or agency shares stockholding obligations with the industry. The industry is not involved in stockholding activities in the Czech Republic, Malta, Slovakia, and Slovenia. Two of these countries, i.e. the Czech Republic and Slovakia, have centralised systems in place in which governmental units hold all emergency stocks (European Commission, 2008, p. 45; Administration of State Material Reserves of the Czech Republic, 2011; Administration of State Material Reserves of Slovakia, 2011). Another interesting case is the Hungarian model, which relies on an independent non-profit company that is owned by oil and petroleum companies but fully controlled by the state (EIHP-PDC, 2011, p. 20f.).

Stockholding systems that rely on government or agency stocks are generally better prepared for emergency situations since the oil can be provided immediately. By the same token, however, mixed systems such as the Polish one possess the advance that the costs associated with the formation and maintenance of emergency oils can be split between the industry and the state (Material Reserves Agency of Poland, 2011).

While the majority of the new Member States established a governmental unit or an agency endowed with the competence of organising activities related to oil stockholding, a corresponding organisation is absent in Latvia. In fact, in July 2009 the Latvian government closed the Construction, Energy and Building State Agency by Cabinet Order no. 353, which until then used to be responsible for stockholding. Currently, the Ministry of Economics is charged with this function. Within the ministry there is a special energy department consisting of two persons who - in cooperation with the industry - maintain all establishments of emergency oil stocks (Ministry of Economics of Latvia, 2011).

Table 2

Overview of stockholding systems in the Member States

\begin{tabular}{lllc}
\hline Member & Governments Unit/Agency & Industry & Stocks abroad \\
\hline Bulgaria & State Reserve and War-time Stocks & $\times$ & $\times$ \\
Cyprus & Cyprus Organisation for the Storage and Management of Oil Stocks & $\times$ & $\times$ \\
Czech Republic & Administration of State Material Reserves & $\times$ & $\times$ \\
Estonia & Estonian Oil Stockpiling Agency & $\times$ & \\
Hungary & Hungarian Hydrocarbon Stockpiling Association & $\times$ & $\times$ \\
Latvia & No specific agency: Ministry of Economics & $\times$ & \\
Lithuania & Lithuanian Petroleum Products Agency & $\times$ & \\
Malta & Malta Resources Authority & & \\
Poland & Material Reserves Agency & & \\
Romania & National Administration of State Reserves & & \\
Slovakia & Administration of State Material Reserves & & $\times$ \\
Slovenia & Agency for Commodity Reserves & \\
\hline
\end{tabular}

Notes: Own elaboration based on IEA (2007, p. 34), Lithuanian Energy Institute (2003, p. 36), Ministry of Economics of Latvia (2003) and the

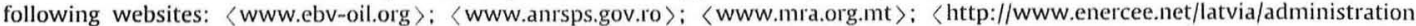
html $\rangle$, all accessed on 13 August 2011. 
Five countries established stocks on the territory of another Member State. The Czech Republic holds stocks in Germany, whereas Slovenia has storage agreements in place with Germany, Italy, Portugal, and Hungary. As concerns Cyprus, a considerable part of the stocks of oil category II is stored in Greece, but the country has also concluded agreements with Italy and the Netherlands. ${ }^{2}$ Lithuania mainly relies on the other two Baltic States for using their storage capacity, whereas Estonia has established one of the broadest cooperation networks, comprising Denmark, Germany, Sweden and Finland as well as Latvia and Lithuania.

\section{Explaining compliance with Council Directive 2006/67/EC}

This section sheds light on the causes underlying the challenges the Latvian government faces for meeting the EU obligations for oil categories I and II. Moreover, it seeks to provide a more general explanation for the cross-country variation in stock levels. In so doing, the empirical illustrations follow the theoretical considerations presented in Section 4.

\subsection{Explaining Latvia's transposition problems}

There are two structural characteristics that distinguish Latvia from many other new Member States. Firstly, Latvia does not produce any petroleum products and is therefore strongly dependent on oil imports. ${ }^{3}$ Secondly, Latvia was more severely hit by the financial crisis of 2008-2009 than most other new Member States with a reduction of its Gross Domestic Product by 18 per cent (see Mayes, 2009, p. 1006). ${ }^{4}$ It is with this knowledge that the situation of emergency oil stocks in Latvia must be interpreted.

According to information provided by the Ministry of Economics of Latvia (2011), there is currently no available financing for the establishment of oil stocks or the strengthening of the corresponding institutional structures. In fact, the closure of the Construction, Energy and Building State Agency was a direct consequence of the budgetary constraints emerging from the financial crisis. However, the difficulties in funding the oil stocks rather seem to have been aggravated than caused by the recent economic developments. In 2000 already, the Latvian government stated that the establishment of appropriate oil stocks would need a period of $10-25$ years. ${ }^{5}$ Further, in another position paper on the acquis' energy chapter, the government specifically asked for an extended transposition deadline until 31 December 2010 in order to be able to collect the necessary financial resources (Ministry of Foreign Affairs of Latvia, 2003).

That being said, the financial issues in Latvia do not emerge from the potential costs of developing storage capacity, but from the costs of acquisition. In fact, until the Soviet Union fell apart, the Latvian port of Ventspils was an important outlet for Russian oil exports and the country therefore possesses the requisite infrastructure for meeting the stockholding obligations. The existence of storage capacity is also reflected in the bilateral storage agreements that Latvia concluded with Denmark, Estonia, Finland and Lithuania (Ministry of Economics of Latvia, 2010). Moreover, the Ministry of Economics of Latvia (2011) explained that once purchased, the entire amount of necessary stocks could be stored in Latvia.

\footnotetext{
$2<$ http://www.mcit.gov.cy/mcit/mcit.nsf/dmloil_en/dmloil_en?OpenDocu ment $>$, accessed on 11 June 2011.

$3<$ http://www.eia.gov/countries/country-data.cfm?fips=LG > accessed 13 August 2011. The other two countries that do not produce oil are Cyprus and Malta.

${ }^{4}<$ http://data.worldbank.org/indicator/NY.GDP.MKTP.KD.ZG > , accessed 13 August 2011.

$5<$ http://europa.eu/legislation_summaries/enlargement/2004_and_2007_en largement/latvia/e14104_en.htm > , accessed on 13 August 2011.
}

To solve the problems in the transposition of Council Directive 2006/67/EC, the Latvian government may, in principal, increase cooperation with its neighbouring states. In this context, collaboration with Russia is, however, unlikely since the relations between both countries became strained, partly because of disagreement over the pipeline-transit and port-loading fees charged by Latvia (Bhagat, 2004, p. 142f). In fact, Russia ceased utilising the pipeline to Ventspils in 2003 (Baran, 2007, p. 132). A more likely scenario is that Latvia cooperates with Estonia and Lithuania to develop sufficient emergency oil stocks. Preliminary talks are currently ongoing in order to discuss possible avenues for creating one central stock-maintaining structure in the Baltic States by 2030 (Ministry of Economics of Latvia, 2011).

There are also more concrete measures that the Latvian government has already taken to remedy the transposition deficit. On 4 August 2009, the Cabinet of Ministers adopted a decision to commit the Ministry of Economics to prepare a new 'Conception of Establishment of Emergency Oil Stocks', which came into force on 29 March 2010. Along with this legal act, the Law on Taxes and Fees and the Energy Law were modified in June 2010 to ensure that the country acquires the necessary financial means for complying with the Directive (Ministry of Economics of Latvia, 2010). If these measures will be effective still remains to be seen. When considering the stockholding situation in 2011, however, a swift improvement seems unlikely.

To sum up, Latvia's problems in complying with the EU stockholding requirements stem from budgetary constraints and the lacking domestic oil production capacity. Although the country benefited from a comparatively long grace period, it could not achieve compliance with Council Directive 2006/67/EC. There is, however, no evidence suggesting that the government systematically delayed necessary reforms because of the long grace period. Consequently, there is no evidence in favour of hypothesis $1 \mathrm{a}$ or $1 \mathrm{~b}$. It is also difficult to make a reliable statement about the role of IEA membership. Latvia is indeed no IEA member, but on the basis of the available empirical information it is virtually impossible to evaluate how this affected the adjustment process. Hence, the Latvian case study only provides support for Hypotheses 3 and 4 . However, this raises the question about the more general relevance of these factors for cross-country differences in the stock levels.

\subsection{Explaining cross-country variation}

To elucidate the determinants of the new Member States' absolute stock levels (regardless of whether they under- or overcomply with the 90-days obligation), this section presents a regression analysis with panel data. ${ }^{6}$ The dependent variable is measured by the combined stocks levels for the three oil categories in 2008, 2009 and 2010. The values for 2011 had to be excluded since no data was available for the independent variables.

The variable Grace Period indicates the duration of the extended transposition deadline for Council Directive 2006/67/EC as reported in Table 1, ranging from zero to seven years. The variable IEA reports for how many years a country has been an IEA member. According to the information provided on the organisation's official website, of the twelve countries under study only four are IEA members, i.e. the Czech Republic (joined: 2001), Hungary (joined: 1997), Poland (joined: 2008) and Slovakia (joined: 2007). To assess a country's economic situation, the annual growth in its Gross Domestic Product (GDP; in constant 2000 US Dollars) as reported

\footnotetext{
${ }^{6}$ The estimation models performed here are linear regressions with panelcorrected standard errors with corrections for autocorrelation AR(1). An equally or arguably even more suitable estimation model would have been provided by a Tobit regression since the data is, in principle, subject to censoring. However, the small number of observations prevented the use of this technique.
} 
Table 3

Regression analysis of absolute oil stocks levels (categories 1-III)

\begin{tabular}{|c|c|c|c|c|c|c|c|c|c|c|}
\hline & \multicolumn{2}{|l|}{ Model 1} & \multicolumn{2}{|l|}{ Model 2} & \multicolumn{2}{|l|}{ Model 3} & \multicolumn{2}{|l|}{ Model 4} & \multicolumn{2}{|l|}{ Model 5} \\
\hline & $\beta$ & SE & $\beta$ & SE & $\beta$ & SE & $\beta$ & SE & $\beta$ & SE \\
\hline Grace period & -0.68 & $(1.70)$ & -4.52 & (3.13) & - & - & - & - & - & - \\
\hline IEA membership & 3.36 & $(1.49)^{* * *}$ & - & - & 5.86 & $(2.78)^{\text {sok }}$ & - & - & - & - \\
\hline GDP growth & 1.21 & $(0.25)^{k \text { k*t }}$ & - & - & - & - & 1.45 & $(0.35)^{* 4 *}$ & 1.45 & $(0.35)^{* * * *}$ \\
\hline Oil production & 4.40 & $(1.37)^{*+* * *}$ & - & - & - & - & - & - & 3.43 & $(0.58)^{\text {*ats }}$ \\
\hline Lagged DV & 1.02 & $(0.23)^{* k \cdot k \pi}$ & 1.00 & $(0.36)^{* k-k \pi t h}$ & 0.85 & $(0.34)^{k-k}$ & 1.22 & 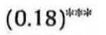 & 1.17 & $(0.28)^{*, k 4 t}$ \\
\hline Constant & 2.25 & $(31.28)$ & 32.36 & $(51.87)$ & 20.16 & $(34.15)$ & -20.57 & (17.27) & -5.51 & $(31.74)$ \\
\hline$N$ & 24 & & 24 & & 24 & & 24 & & 24 & \\
\hline Wald $\chi^{2}(\mathrm{DF})$ & $44.70(3)^{\text {kth }}$ & & $65.87(2)^{k+1 / 5}$ & & $39.21(2)^{2.00}$ & & 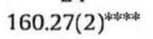 & & $43.00(2)^{\infty}$ & \\
\hline$R^{2}$ & 0.93 & & 0.78 & & 0.83 & & 0.94 & & 0.85 & \\
\hline
\end{tabular}

Notes: Linear regression with panel-corrected standard errors with corrections for autocorrelation $\mathrm{AR}(1)$; independent variables lagged by one year; $\beta=$ coefficients; $\mathrm{SE}=$ standard errors; $\mathrm{DV}=$ dependent variable; $\mathrm{DF}=$ degrees of freedom.

$$
\begin{aligned}
& \begin{array}{l}
{ }^{*} p<0.1 . \\
* \neq * \\
p<<0.05
\end{array} \\
& \text { *⿻大从t } p<0.01 \text {. }
\end{aligned}
$$

by the World Bank's World Development Indicators is employed. Data on the domestic oil production capacity is taken from the International Energy Statistics provided by the United States Energy Information Administration. The data is adjusted by the population size as reported by the World Development Indicators to facilitate comparison. All independent variables are lagged by one year to ensure that there is a delay between cause and effect. Moreover, as the analysis is based on panel data, the estimation models include a lagged dependent variable as a regressor to account for dynamic effects (see, e.g. Beck and Katz, 1995; Kittel, 1999).

Table 3 presents five estimation models. Model 1 is the extensively fitted model including all regressors. Models $2-5$ only include the lagged dependent variable and one independent variable each to make sure that the findings are robust across different model specifications. Despite the low number of observations $(N=24)$, the regression analyses perform well and produce significant coefficients with the predicted signs for all independent variables but the length of the grace periods.

The results are interpreted as follows: A longer IEA membership increases the likelihood of higher stocks levels, ceteris paribus. Likewise, economic growth has a positive impact on stocks levels, holding everything else constant. Finally, new Member States with greater domestic oil production capacities are associated with higher stock levels, ceteris paribus. Therefore, the theoretical considerations underlying Hypotheses 2-4 can be confirmed, whereas there is again no evidence supporting hypothesis $1 \mathrm{a}$ or $1 \mathrm{~b}$.

The broader implication of this finding is that there is no automatism between extended transposition deadlines and compliance. Grace periods can be a means to facilitate compliance but the additional time gained by the governments must be indeed used to increase their financial capacities. Another, arguably more effective way to achieve high stock levels is to begin early with reducing the distance between the initial stockholding system and the requested one. This finding corresponds well with a central insight provided by the study of Knill and Tosun (2009), i.e. that the new Member States' efforts to align their policies and institutions with the European ones in the pre-accession stage are decisive for their transposition performance in the post-accession stage.

\section{Conclusion}

This exploratory study investigated the situation regarding emergency oil stocks in the new Member States of the EU. In so doing, it posed two core research questions: Why did the accession candidates (almost) uniformly ask for transitional arrangements for meeting the provisions of this particular directive? What does the transposition situation look like now that the grace period has ended for most of the new Member States? The main argument presented by the accession candidates during the negotiation of the energy acquis was that the development of emergency oil stocks at the requested levels would entail considerable financial costs that needed to be spread over multiple budgetary years. In most cases, this strategy proved effective and compliance with the Council Directive 2006/67/EC was achieved. It only did not work out for Latvia, which has faced persistent problems in meeting the EU obligations for two of the three oil types regulated. Essentially, this situation can be attributed to the considerable financial restrictions the country is currently experiencing and the generally elevated compliance costs stemming from a lacking capacity to produce oil and petroleum products.

More generally, the stockholding levels not only depend on the financial burdens but also on the degree of misfit between the domestic institutional arrangements and the EU requirements. Hence, countries that are IEA members more likely to meet or even exceed the EU requirements as they already had to align their national stockholding systems with the international obligations when they entered this organisation.

All in all, however, this study just provides a 'snapshot' of the current state of compliance with Council Directive 2006/67/EC and the situation might look markedly different in a few years with the EU accession of further countries. In fact, the European Commission seems to have learned from the experience it made with the last two accession rounds and aims to induce anticipatory compliance with the energy acquis by means of the Energy Community (see, e.g. Prange-Gstöhl, 2009). Therefore, this analysis must rather be seen as a starting point than a conclusive analysis of the determinants of compliance with EU energy legislation. Thus, it will depend on future research to show whether the causal relationships identified in this article hold equally true in other analytical settings.

\section{Acknowledgements}

I would like to thank Anete Jurcika for supporting me in gathering empirical information on Latvia as well as three anonymous reviewers for their helpful comments on earlier versions of this article. I am also grateful to Jan Bartoš, Dainius Braziunas, Alan Vaht, Ladislav Zabo, the Ministry of Economics of 
Latvia and the Administration of State Material Reserves of Slovakia for providing me assistance in data collection.

\section{References}

Administration of State Material Reserves of the Czech Republic, 2011. Response to Email Inquiry. 17 May 2011.

Administration of State Material Reserves of Slovakia, 2011. Response to Email Inquiry. 20 May 2011.

Bankes-Hughes, L., 2011. Tacking stock: strategic oil reserves. Bunkerspot 8 (2), 32-36.

Baran, Z., 2007. EU energy security: time to end Russian leverage. The Washington Quarterly $30(4), 131-144$

Beck, N., Katz, J.N., 1995. What to do (and not to do) with time-series-cross-section data in comparative politics. American Political Science Review 89 (3). 634-647.

Bhagat, G., 2004. Russia's oil potential: prospects and implications. OPEC Review 28 (2) 133-147.

Börzel, T.A., 2000. Why there is no 'southern problem': on environmental leaders and laggards in the European Union. Journal of European Public Policy 7 (1), $141-162$

Buchan, D., 2009. Energy and Climate Change: Europe at the Crossroads. Oxford University Press, Oxford.

Buchan, D. 2010. Energy policy: sharp challenges and rising ambitions In: Wallace, H., Wallace, W., Pollack, M. (Eds.), Policy-Making in the European UnionOxford University Press, Oxford, pp. 357-380

Chester, L., 2010. Conceptualising energy security and making explicit its polysemic nature. Energy Policy 38 (2), 887-895.

Cirtautas, A.M., Schimmelfennig, F., 2010. Europeanisation before and after accession: conditionality, legacies and compliance. Europe-Asia Studies 62 (3), 421-441

Correljé, A., van der Linde, C., 2006. Energy supply security and geopolitics: a European perspective. Energy Policy 34 (5), 532-554.

Duina, F.G., 1997. Explaining legal implementation in the European Union. International Journal of the Sociology of Law 25 (2), 155-179.

EIHP-PDC, 2011. Emergency Oil Stocks in the Energy Community Level-Final Report. Available at: 〈http:/www.energy-community.org/pls/portal/docs/ 1014177.PDF $\rangle$ (accessed on 13 August 2011).

Eikeland, P.O., 2008. EU Internal Energy Market Policy: New Dynamics in the Brussels Policy Game? FNI Report 14/2008. Available at: 〈http:/www.fni.no/ doc\&pdf/FNI-R1408.pdf> (accessed on 11 June 2011).

Emerson, S.A., 2006. When should we use strategic oil stocks? Energy Policy 34 (18), 3377-3386.

European Commission, 2008. Commission Staff Working Document: Accompanying Document to the Proposal for a Directive of the Council Imposing an Obligation on Member States to Maintain Minimum Stocks of Crude Oil and/or Petroleum Products. Available at: 〈http://ec.europa.eu/energy/strategies/ 2008/doc/2008_11_ser2/oil_stocks_impact_assesment.pdf > (accessed on 11 June 2011).

European Commission, 2011. Priorities for 2020 and Beyond-A Blueprint for an Integrated European Energy Network. European Commission, Brussels.

Falkner, G., Treib, O., 2008. Three worlds of compliance or four? The EU-15 compared to New Member States. Journal of Common Market Studies 46 (3), 293-313.

IEA, 2001. Oil Supply Security-The Emergency Response Potential of IEA Countries in 2000. IEA/OECD, Paris.

IEA, 2007. Oil Supply Security-Emergency Response of IEA Countries 2007. IEA/ OECD, Paris.

Katinas, V., Markevicius, A., Erlickyte, R., Marciukaitis, M., 2008. Governmental policy and prospect in electricity production from renewables in Lithuania. Energy Policy 36 (10), 3686-3691.

Kittel, B., 1999. Sense and sensitivity in the pooled analysis of political data. European Journal of Political Research 35 (2), 225-253.

Knill, C., Lenschow, A., 1998. Coping with Europe: the impact of British and German administrations on the implementation of EU environmental policy. Journal of European Public Policy 5 (4), 595-614.

Knill, C., Tosun, J., 2009. Post-accession transposition of EU law in the new Member States: a cross-country comparison. European Integration online Papers (Special Issue) 2 (13). Available at: 〈http/eiop.or.at/eiop/ index.php/eiop/article/viewFile/2009_018a/134 > (accessed on 11 June 2011).

König. T., Luetgert, B., 2008. Troubles with transposition? Explaining trends in Member-State notification and the delayed transposition of EU Directives. British Journal of Political Science 39 (1), 163-194.

Leiby, P.N., Bowman D., Jones, D.W., 2002. Improving Energy Security Through an International Cooperative Approach to Emergency Oil Stockpiling. Available at: 〈http://citeseerx.ist.psu.edu/viewdoc/summary?doi=10.1.1.138.5120〉 (accessed on 11 June 2011).

Lithuanian Energy Institute, 2003. National Energy Strategy. Lithuanian Energy Institute, Riga.

Lofstedt, R., 2008. Are renewables an alternative to nuclear power? An analysis of the Austria/Slovakia discussions. Energy Policy 36 (6), 2226-2233.
Mastenbroek, E., 2005. EU compliance: still a 'Black Hole'? Journal of European Public Policy 12 (6), 1103-1120.

Material Reserves Agency of Poland, 2011. Response to Email Inquiry. 26 May 2011.

Mayes, D.G., 2009. Did recent experience of a financial crisis help in coping with the current financial turmoil? The case of the Nordic Countries. Journal of Common Market Studies 47 (5), 997-1015.

Ministry of Foreign Affairs of Latvia, 2003. Position Paper of the Republic of Latvia on Chapter 14: "Energy". Available at: 〈http:/www.am.gov.lv/en/eu/history/ 4358/4359/4373/> (accessed on 11 June 2011)

Ministry of Economics of Latvia, 2003. Standard Summary Project Fiche. Available at: 〈http:/ec.europa.eu/enlargement/fiche_projet/work/2003-004-979.05.01\%20 Administration\%20of\%20oil\%20stock\%20reserve\%20system.pdf?CFID $=3552783 \&$ CFTOKEN=9cf672521 eeeda05-E2704DD7-9682-7E95-FADE9COD936311B9\&jses sionid $=060135120 f 5543711422>$ (accessed on 11 June 2011).

Ministry of Economics of Latvia, 2010. Response to Email Inquiry. 15 December 2010.

Ministry of Economics of Latvia, 2011. Response to Email Inquiry. 20 May 2011.

Miskinis, V., Deksnys, R., 2003. Management changes in the Lithuanian energy sector. International Journal of Risk Assessment and Management $4(2 / 3)$ 145-157.

Morata, F., Solorio, I. (Eds.), 2011. Autonomous University of Barcelona Press, Barcelona.

Nilsson, M., Nilsson, L.J., Ericsson, K., 2009. The rise and fall of Go trading in European renewable energy policy: the role of advocacy and policy framing. Energy Policy 37 (11), 4454-4462.

Nowak, B., 2007. Adaptation of the polish gas and electricity sector to the requirements of the EU internal market directives-how far to the competitive electricity and gas market? Legal and business perspective. Yearbook of Polish European Studies $11(1), 61-84$.

Padrós, C., Cocciolo, E.E., 2010. Security of energy supply: when could national policy take precedence over European law? Energy Law Journal 31 (1) 31-54.

Perkins, R., Neumayer, E., 2007. Do membership benefits buy regulatory compliance? An empirical analysis of EU Directives 1978-1999. European Union Politics 8 (2), 180-206

Pointvogl, A., 2009. Perceptions, realities, concession-what is driving the integration of European energy policies? Energy Policy 37 (12), 5704-5716.

Prange-Gstöhl, H., 2009. Enlarging the EU's internal energy market: why would third countries accept EU rule export? Energy Policy 37 (12), 5296-5303.

Schneider, C.J., 2009. Conflict, Negotiation and European Union Enlargement. Cambridge University Press, Cambridge.

Schimmelfennig. F., Trauner, F. (Eds.), 2009. Post-accession Compliance in the EU's New Member States. European Integration Online Papers (Special Issue) 2(13) Available at: 〈http:/eiop.or.at/eiop/index.php/eiop/issue/view/22〉 (accessed on 11 June 2011).

Sedelmeier, U., 2008. After conditionality: post accession compliance with EU law in East. Central Europe. Journal of European Public Policy 15 (6), 918-937.

Semov, A., 2005. The Kozloduy absurdity: legal and political dimensions of the Bulgarian Nuclear Power Plant issue. International Journal of Nuclear Governance, Economy and Ecology 1 (1), 11-28.

Solorio, I., 2011. Environmental Policy Integration (EPI) and the Europeanisation of the energy governance. In: Morata, F., Solorio, I. (Eds.), European Energy Policy: The Environmental DimensionAutonomous University of Barcelona Press, Barcelona, pp. 75-94.

Steunenberg, B., Kaeding, M., 2009. As time goes by: explaining the transposition of maritime directives. European Journal of Political Research 48 (3), $432-454$

Strandberg, U., 2010. Security, prosperity and community-towards a common European energy policy? Energy Policy 38 (3), 1227-1251.

Tallberg, J., 2002. Paths to compliance: enforcement, management and the European Union. International Organization 56 (3), 609-643.

Toshkov, D., 2008. Embracing European Law: transposition of EU directives in Central and Eastern Europe. European Union Politics 9 (3), 342-379.

Times of Malta, 2002. EU Membership-Negotiations on Energy Concluded. Available at: 〈http://www.timesofmalta.com/articles/view/20020817/local/ negotiations-on-energy-concluded > (accessed on 11 June 2011).

Treib, O., 2008. Implementing and Complying with EU Governance Outputs. Living Reviews in European Governance 3(5). Available at: 〈http://www.livingre views.org/lreg-2008-5> (accessed on 11 June 2011).

Willenborg, R., Tönjes, C., Perlot, W., 2004. Europe's oil defences. An analysis of Europe's oil supply vulnerability and its emergency oil stockholding systems. Journal of Energy Literature 10 (2) Available at: 〈http:/www.oxfordenergy. org/jelindex.php> (accessed on 11 June 2011)

Umbrasas, G., 2001. Evaluation of Consequences of Council Directive 98/93/EC Amending Directive 68/414/EEC Imposing an Obligation on Member States of the EEC to Maintain Minimum Stocks of Crude Oil and/ or Petroleum Products. Available at: <http:/www.euro.1t/documents/poveikio_tyrimai/angliski_ir_ve liau_ikelti_dokumentai/2001/Min._naftos_atsargos_sum_en.pdf $\rangle$ (accessed on 11 June 2011). 